\title{
Signaling Protein
}

National Cancer Institute

\section{Source}

National Cancer Institute. Signaling Protein. NCI Thesaurus. Code C18515.

Proteins or peptides that participate in signal transduction processes in the cell. 